\title{
Pengaruh Job Demands dan Job Resources terhadap Work Engagement Guru
}

\author{
Izzah Ramadhani Astisya \\ Program Studi Magister Psikologi Profesi, Fakultas Psikologi, \\ Universitas Airlangga \\ cacaramadhaniastisya@gmail.com \\ Cholichul Hadi \\ Program Studi Magister Psikologi Profesi, Fakultas Psikologi, \\ Universitas Airlangga \\ cholichul.hadi@psikologi.unair.ac.id
}

\begin{abstract}
Employees who are engaged in their jobs will be more committed to the organization, are less often absent, and do not intend to leave the organization (Schaufeli, 2012). Teaching is like any other profession that requires work engagement. The factor that is often used to explain its effect on work engagement are job demands and job resources. Every teachers have to deal with job demands at work and requires job resources to support them. The aims of the study is to determine the effect of job demands and job resources on work engagement. This research was conducted on 184 teachers who teach in elementary school, junior and senior high school. Data was collected by using questionnaire forms of a UWES-9 scale and JDRS scale. The data was analyzed by ordinal regression and the result shows that job demands and job resources did not affect work engagement on teacher.
\end{abstract}

Key words: work engagement; job demands; job resources; teachers

\begin{abstract}
Abstrak
Karyawan yang merasa engaged dengan pekerjaannya akan lebih berkomitmen terhadap organisasi, lebih jarang absen, dan tidak memiliki keinginan untuk meninggalkan organisasi (Schaufeli, 2012). Profesi guru sama seperti profesi lainnya yang membutuhkan work engagement. Faktor yang sering digunakan untuk menjelaskan pengaruhnya terhadap work engagement adalah job demands dan job resources. Mengajar adalah suatu pekerjaan yang juga dihadapkan pada job demands dan membutuhkan job resources yang mendukung agar dapat berlangsung dengan efektif. Penelitian ini bertujuan untuk mengetahui pengaruh dari job demands dan job resources terhadap work engagement. Penelitian ini dilakukan pada 184 guru yang mengajar di sekolah pada jenjang SD, SMP, dan SMA/SMK. Teknik sampling yang digunakan adalah snowball sampling. Alat pengumpul data dalam penelitian ini menggunakan kuisioner berupa skala
\end{abstract}


UWES-9 untuk dan skala JDRS untuk. Analisis data menggunakan regresi ordinal menunjukkan bahwa tidak ada pengaruh antara job demands dan job resources terhadap work engagement pada guru.

Kata kunci: work engagement; job demands; job resources; guru

\section{Pendahuluan}

Pendidikan adalah salah satu tahapan penting dalam pembentukan masyarakat karena pendidikan adalah sebuah sistem yang secara menyeluruh memberikan wawasan dan pengetahuan, serta mengajarkan moralitas, sikap, dan keterampilan. Sistem pendidikan membutuhkan lembaga yang dalam hal ini adalah sekolah dan tenaga pengajar untuk dapat menjalankan sistem tersebut. Guru adalah poin paling penting dalam setiap sekolah yang memiliki peran dan tanggung jawab untuk proses pendidikan. Jika ada keberhasilan atau kegagalan dalam kemajuan pendidikan, guru memiliki peran besar didalamnya.

Profesi guru di Indonesia telah diatur dalam Undang-undang nomor 14 tahun 2005 tentang Guru dan Dosen. Pada undang-undang tersebut tertulis berbagai persyaratan dan tuntutan dasar yang harus dipenuhi oleh guru untuk dapat menjalankan tugasnya. Selain tuntutan yang telah tertulis dalam undangundang, masih banyak tuntutan lain yang tidak tertulis yang diharapkan dapat dipenuhi oleh guru. Seorang guru diharapkan untuk mampu melakukan interaksi yang baik dengan siswa dan orang tua siswa. Selain itu, guru juga dituntut untuk dapat menjadi contoh yang baik bagi siswanya.

Seiring dengan berjalannya waktu, perkembangan dan perubahan dalam dunia pendidikan juga telah banyak terjadi. Di Indonesia sendiri dalam kurun waktu 20 tahun terakhir telah terjadi perubahan kurikulum sebanyak lima kali. Perubahan sistem belajar-mengajar dan perkembangan teknologi juga menuntut guru untuk terus mengembangkan dan meningkatkan kemampuan diri agar dapat memberikan kinerja yang optimal. Dibutuhkan individu yang memiliki energi dan 
semangat yang tinggi, dedikasi, serta terlibat sepenuhnya dalam pekerjaannya untuk memperoleh kinerja yang optimal.

Karakteristik tersebut merupakan karakeristik dari individu yang merasa engaged terhadap pekerjaannya. Individu atau karyawan yang merasa engaged dengan pekerjaannya, selain memiliki energi dan semangat yang tinggi, mereka juga akan terhubung dengan aktifitas pekerjaannya dan mampu menerima dengan baik tuntutan dari pekerjaan mereka (Schaufelli, dkk., 2002). Schaufelli, dkk. (2002) mendefinisikan work engagement sebagai kondisi pikiran yang positif dan sepenuhnya melibatkan diri dalam pekerjaan yang ditandai dengan adanya vigor, dedication, dan absorption.

Vigor, dedication, dan absorption merupakan tiga dimensi dari work engagement. Vigor dikarakteristikkan dengan tingkat energi yang tinggi dan resiliansi mental selama bekerja, kesediaan untuk melakukan usaha yang lebih dalam menyelesaikan pekerjaan, serta gigih dalam menghadapi kesulitan saat bekerja (Schaufelli, dkk., 2002). Dedication menurut Rothmann dan Jordaan (2006) adalah kondisi pada saat individu merasa terinspirasi oleh pekerjaannya, merasa antusias terhadap pekerjaannya, dan merasa tertantang dalam menyelesaikan pekerjaannya. Dimensi terakhir adalah absorption yang ditandai dengan konsentrasi penuh pada saat bekerja sehingga waktu terasa berlalu dengan cepat dan terasa sulit untuk melepaskan diri dari pekerjaan (Schaufelli, dkk., 2002).

Organisasi modern yang ingin tetap mampu bersaing membutuhkan karyawan yang engaged dengan pekerjaannya, individu yang penuh energi dan antusiasme (Bakker, 2017). Hal tersebut merupakan salah satu alasan mengapa work engagement menjadi penting. Burke dan El-Kot (2010) menyebutkan bahwa karyawan yang merasakan work engagement akan dengan antusias menerima tantangan dalam pekerjaan. Menurut Burke dan El-Kot (2010) work engagement memberikan dampak "yang kaya akan semakin kaya”, artinya karyawan yang engaged dengan pekerjannya akan memberikan usaha lebih dan akan mendapatkan hasil yang lebih pula. 
Pada beberapa penelitian disebutkan bahwa work engagement memberikan dampak yang positif pada karir karyawan. Karyawan yang merasa engaged dengan pekerjaannya tidak hanya termotivasi untuk mencapai tujuan jangka pendek tetapi juga secara simultan menumbuhkan gairah pada pekerjaan dan karir meraka, dapat menciptakan sumber daya permanen yang dapat membantu mereka mempertahankan aspek positif terkait karir mereka seperti career satisfaction, career commitment, dan rendahnya turnover intention (Barnes dan Collier, 2013; Karatepe, 2012; Laschinger, 2012). Matthysen dan Harris (2018) dalam penelitiannya menyimpulkan bahwa karyawan dengan level work engagement yang tinggi akan mengahasilkan readiness to change. Karyawan yang merasa engaged dengan pekerjaannya akan mampu lebih baik dalam menghadapi tuntutan kerja selama proses perubahan dalam organisasi yang juga akan menentukan keberhasilan dari perubahan tersebut.

Dampak yang mungkin terjadi apabila karyawan merasa engaged dengan pekerjaannya adalah sikap positif dalam bekerja, lebih sehat secara fisik maupun mental, dan dampaknya terhadap kinerja (Schaufelli dan Salanova, 2007; Christian, dkk., 2011; Halbesleben, 2010). Karyawan yang merasa engaged dengan pekerjaannya akan menunjukkan kinerja yang lebih baik dari mereka yang tidak merasa engaged (Rich, dkk., 2010; Halbesleben, 2010). Menurut Schaufeli (2012), karyawan yang engaged dengan pekerjaannya akan lebih sedikit melakukan kesalahan, lebih jarang mengalami kecelakaan kerja, menunjukkan perilaku kerja yang lebih inovatif, dan mendapatkan penilaian yang lebih baik dari atasan dalam hal efektivitas dan kinerja pekerjaan. Apabila dibandingkan dengan karyawan yang tidak merasa engaged dengan pekerjaannya, mereka yang merasa engaged akan lebih berkomiten terhadap organisasi, lebih jarang absen, dan tidak ada keinginan untuk meninggalkan organisasi (Schaufeli, 2012).

Schaufeli (2012) mengatakan dampak work engagement tidak hanya dirasakan oleh organisasi tetapi juga oleh karyawan. Karyawan yang engaged dengan pekerjaannya akan meraskan emosi yang positif jika dibandingkan dengan karyawan yang workaholics. Mereka akan menunjukkan inisiatif dan kemauan yang kuat untuk belajar yang mana hal tersebut menunjukan bahwa karyawan 
yang engaged akan mampu dan bersedia untuk bekerja lebih keras (Schaufeli, 2012). Schaufeli (2012) juga menyebutkan bahwa karyawan yang merasakan engagement pada pekerjaannya akan bekerja keras karena bagi mereka pekerjaan adalah hal yang menantang dan menyenangkan.

Work engagement dapat memberikan manfaat lain seperti kontak sosial, pengetahuan, self-esteem, dan self-efficay yang terbukit dapat menjadi sumber daya penting untuk keberhasilan mereka dalam menjalankan fungsinya di masyarakat diluar lingkup pekerjaan (Salanova, dkk., 2011; Salanova, dkk., 2010). Eldor, dkk. (2016) menyebutkan bahwa pada saat karyawan merasa engaged dengan pekerjaannya maka akan mempengaruhi bagaimana mereka bersikap diluar lingkungan kerja, seperti bagaimana sikap mereka mengenai kepuasan dalam hidup dan keterlibatan mereka dalam masyarakat. Work engagement juga memiliki potensi untuk memperkaya keterlibatan individu dalam masyarakan dan dalam konteks sosial lainnya (Eldor, 2016).

Work engagement sendiri dipengaruhi oleh banyak faktor. Bhuvanaiah dan Raya (2016) menyatakan bahwa budaya organisasi secara signifikan berpengaruh terhadap work engagement terutama pada organisasi yang memprioritaskan nilainilai dari karyawannya untuk menetapkan standar budaya yang mendukung organisasi. Pada penelitian yang dilakukan Soares dan Mosquera (2019) menemukan bahwa kontrak psikologis memiliki dampak terhadap work engagement. Soares dan Mosquera (2019) menyebutkan bahwa relational contract (provide socio-emotional) dan balanced contract (developmental support) memiliki dampak positif yang signifikan terhadap work engagement.

Faktor lain yang mempengaruhi work engagement adalah personality. Beberapa penelitian (Xanthapoulou, dkk., 2009; Jawahar dan Liu, 2017) menyebutkan bahwa personality merupakan salah satu faktor yang mempengaruhi work engagement. Jawahar dan Liu (2017) secara lebih spesifik meneliti tentang hubungan proactive personality terhadap work engagement. Hasil penelitian tersebut menunjukkan bahwa proactive personalitiy adalah salah satu personalitiy traits yang lebih relevan untuk memprediksi work engagement. 
Faktor-faktor yang sering digunakan dalam penelitian untuk memprediksi work engagement adalah job demands dan job resources, baik secara terpisah maupun secara bersama-sama. Salah satu model job demands-job resources yang paling sering digunakan adalah Job Demands-Resources (JD-R) model milik Demerouti dan koleganya yang diperkenalkan pertama kali pada tahun 2001. Mekanisme umum JD-R model dalam mempengaruhi work engagement adalah pada saat job resources pada karyawan berada pada level yang tinggi dan dikombinasikan dengan job demands, baik pada level yang tinggi maupun rendah, maka hal tersebut akan menghasilkan motivasi dan engagement yang tinggi pada karyawan (Bakker dan Demerouti, 2007; Schaufeli, dkk., 2009).

Job demands sendiri diartikan sebagai karakteristik dari pekerjaan yang berpotensi membangkitkan ketegangan pada karyawan apabila pekerjaan tersebut melebihi kemampuan adaptasi karyawan (Bakker, dkk., 2007). Job demands pada lingkungan kerja dapat berupa tekanan waktu, tekanan pekerjaan, lingkungan kerja yang buruk, ambiguitas peran dalam pekerjaan, dan beban kerja (Bakker dan Demerouti, 2007). Job resources mengacu pada kondisi pekerjaan atau lingkungan kerja yang menyediakan sumber daya bagi setiap karywan (Bakker dan Demerouti, 2007). Job resources akan berbeda pada setiap levelnya dan terdapat empat level tempat dimana biasanya job resources ditemukan, yaitu level organisasi, level interpersonal and social relations, level organization of work, dan level task atau level tugas (Bakker, dkk., 2004).

Schaufeli, dkk. (2009) menyebutkan bahwa ketika job resources mengalami peningkatan, maka work engagement juga akan cenderung meningkat tetapi perubahan pada job demands tidak mempengaruhi level work engagement di masa depan. Pada penelitiannya, Schaufeli, dkk. (2009) menemukan bahwa job resources memiliki hubungan yang positif dengan work engagement. Dampak dari hubungan positif tersebut adalah ketika karyawan merasakan level work engagement yang tinggi tahun pertama maka akan memprediksi peningkatan job resources pada tahun berikutnya yang juga akan berdampak pada peningkatan work engagement (Schaufeli, dkk., 2009). 
Rothmann dan Jordaan (2006) juga mengemukakan bahwa job resources, seperti kesempatan untuk pengembangan diri, dukungan organisasi, dan kenaikan pangkat mempengaruhi work engagement pada aspek vigour dan dedication. Job demands, dalam hal ini overload, memberi dampak positif pada dedication ketika dukungan organisasi sedang rendah (Rothmann dan Jordaan, 2006). Pada penelitian yang dilakukan Hakanen, dkk. (2008) menunjukkan bahwa keberadaan job resources pasti akan berpengaruh pada work engagement. Menurut Hakanen, dkk. (2008) bahwa karyawan yang memiliki kontrol atas pekerjaan mereka dan merasa dihargai akan menunjukkan work engagement yang tinggi.

Mengajar adalah suatu pekerjaan yang cukup kompleks yang seringkali dibarengi dengan tingginya beban kerja dan tuntutan kerja lainnya. Profesi guru sama seperti profesi lainnya yang membutuhkan work engagement. Guru yang merasa engaged dengan pekerjaannya akan merasa penuh energi dan bekerja dengan efektif, serta diharapakan dapat memberikan hasil yang positif dari pekerjaannya. Yerdelen, dkk. (2018) mengatakan bahwa guru yang merasa engaged dengan pekerjaannya memiliki rasa percaya diri yang lebih besar dalam memegang kendali atas kelasnya.

Bakker dan Bal (2010) menyebutkan bahwa guru yang merasa engaged dengan pekerjaannya akan secara aktif mengerahkan autonomy, dukungan dari rekan kerja, dan peluang pengembangan yang mereka miliki untuk memaksimalkan kinerja. Pada penelitian yang dilakukan Hakanen, dkk. (2006) terhadap guru di Finlandia menunjukkan bahwa guru yang merasa engaged dengan pekerjaannya akan meningkatkan interaksi yang dinamis dengan rekanrekan kerjanya di sekolah. Song, dkk. (2014) mengembangkan kembali penelitian yang dilakukan Hakanen terkait hubungan guru yang engaged dengan rekan kerjanya yang hasilnya menunjukkan bahwa guru yang lebih engaged dengan pekerjaannya akan lebih senang untuk berbagi pengetahuan dengan guru lainnya.

Work engagement pada guru, sama seperti halnya work engagement pada profesi lainnya, memiliki faktor-faktor yang mempengaruhi, job resources dan job demands masih menjadi topik yang banyak digunakan. Hakanen, dkk. (2006) mengatakan bahwa pekerjaan mengajar memiliki banyak job demands. Guru yang 
mampu memanfaatkan job resources seperti job control, dukungan atasan dan inovasi akan lebih engaged terhadap pekerjaan mereka, terutama pada aspek vigor dan dedication (Hakanen, dkk., 2006). Akan tetapi, kurangnya job resources yang penting untuk mendukung pekerjaan guru akan mengurangi work engagement pada guru (Hakanen, dkk., 2006).

Moreira-Fontan, dkk. (2019) menyebutkan bahwa guru yang memiliki job resources, seperti dukungan untuk melakukan inovasi, akan secara mandiri termotivasi dalam pekerjaan mereka dan mengalami vigor, dedication, dan absorption yang lebih kuat. Sarana dan pra-sarana di sekolah merupakan salah satu resources yang berhak diperoleh guru. Pada saat sekolah memberikan fasilitas sarana dan pra-sarana yang baik, guru akan menghabiskan waktu lebih banyak dalam pekerjaannya (Sadeghl dan Sattari, 2018). Menurut Sadeghl dan Sattari (2018), guru yang mendapatkan fasilitas sarana dan pra-sarana yang baik akan lebih berdedikasi pada pekerjaannya, bahkan akan lebih engaged pada sekolah dan pekerjaannya.

Berdasarkan pemaparan tersebut maka penulis tertarik untuk mengkaji tentang pengaruh dari job demands dan job resources terhadap work engagement pada guru. Penelitian mengenai work engagement telah banyak dilakukan sebelumnya pada berbagai macam profesi, tetapi di Indonesia belum banyak yang meneliti work engagement pada guru. Penelitan sebelumnya mengenai work engagement yang dilakukan pada guru oleh Basikin (2007) di Indonesia menggunakan variabel bebas yang berbeda dan menggunakan subyek yang lebih spesifik yaitu guru bahasa inggris pada sekolah menengah. Chen (2017) melakukan penelitian work engagement pada dosen yang mengajar dengan metode synchronous distance education courses.

\section{Metode}

\section{Tipe Penelitian}

Pada penelitian ini, penulis menggunakan pendekatan kuantitatif. Penelitian dengan pendekatan kuantitatif seperti yang dijelaskan Neuman (2014) adalah penelitian yang menggunakan beberapa variabel dan mencari keterkaitan yang ada 
diantara variabel tersebut. Neuman (2014) menyebutkan bahwa terdapat lima bentuk penelitian kuantitatif berdasarkan dari teknik pengumpulan data yang digunakan, yaitu penelitian eksperimental, survey, analisis konten, dan existing statistic. Teknik pengumpulan data yang digunakan pada penelitian ini adalah dengan menggunakan teknik survey. Teknik penelitian survey menurut Neuman (2014) adalah salah satu teknik dalam penelitian kuantitatif dimana peneliti secara sistematis memberikan sejumlah pertanyaan yang sama kepada responden dengan jumlah tertentu dan mencatat setiap jawabannya.

\section{Subyek Penelitian}

Neuman (2014) mendefinisikan populasi sebagai gagasan abstrak dari kelompok besar kasus dimana peneliti mengambil sampel dan hasilnya akan digeneralisasi. Populasi adalah sebuah humpinan dari individu-individu, unit-unit, atau unsur-unsur yang mempunyai ciri-ciri yang sama (Zainuddin, 2011). Karakteristik populasi dalam penelitian ini adalah:

1. Berprofesi sebagai guru atau pengajar.

2. Mengajar siswa pada jenjang pendidikan sekolah dasar dan sederajat, sekolah menengah pertama dan sederajat, serta sekolah menengah atas/kejuruan dan sederajat.

3. Mengajar di sekolah atau madrasah.

Sampel adalah sebagian kecil kasus yang dipilih oleh peneliti dari kelompok besar dan digeneralisasikan pada populasi (Neuman, 2014). Pada penelitian kuantitatif, dibutuhkan usaha yang maksimal untuk menentukan sampel karena tujuannya adalah untuk mendapatkan sampel yang benar-benar merepresentasikan populasi (Neuman, 2014). Penelitian ini menggunakan pendekatan nonprobability sampling dengan teknik pengambilan sampel snowball sampling. Snowball sampling adalah salah satu jenis teknik pengambilan sampel dengan pendekatan nonprobability yang memungkinkan menangkap kasus atau unit yang berada dalam jaringan yang saling terkait (Neuman, 2014). Teknik ini menggunakan analogi bola saju yang digulingkan, dimana yang awalanya kecil akan semakin membesar pada saat digulingkan. 


\section{Teknik Pengumpulan Data}

Pada penelitian survey, proses pengumpulan data dilakukan dengan menggunakan kuesioner (Zainuddin, 2011). Kuisioner pada penelitian ini disebarkan kepada responden secara on-line, yakni melalui media Facebook, Twitter, Instagram, Line, dan Whatsapp. Kuesioner yang digunakan terdiri dari dua skala, yaitu skala work engagement dan skala job demands-resources. Kedua skala tersebut merupakan skala terjemahan dari bahasa inggris menjadi bahasa indonesia yang kemudian dilakukan penerjemahan kembali ke dalam bahasa asli dengan bantuan ahli bahasa.

Kuesioner untuk Work Engagement dalam penelitian ini menggunakan Utrecht Work Engagement Scale (UWES) yang dikembangan oleh Schaufeli, dkk (2002) dimana alat ukur ini tersedia terjemahan dalam Bahasa Indonesia. Utrecht Work Engagement Scale (UWES) terdiri dari 9 aitem pernyataan yang masingmasing mengukur tiga dimensi work engagement yaitu vigor, dedication, dan absorption. Kuesioner untuk job demands dan job resources menggunakan satu skala yang disusun oleh Jackson dan Rothmann (2005) yaitu Job DemandsResources Scale (JDRS). Skala ini terdiri dari tujuh faktor yang mengukur kedua variabel, dimana enam faktor mengukur job resources dan satu faktor mengukur job demands.

\section{Validitas dan Reliabilitas}

Jenis validitas yang digunakan pada alat ukur penelitian ini adalah validitas konstruk (construct validity) yang mana menurut Azwar (2008) merupakan validitas yang menunjukkan sejauh mana suatu tes mengukur trait atau konstruk teoritik yang hendak diukur. Pada skala work engagement, setelah dilakukan uji validitas menunjukkan bahwa koefisien validitas setiap aitem diatas 0,3 yang artinya aitem-aitem tersebut valid dan mampu untuk mencapai tujuan pengukurannya. Pada alat ukur JDRS yang digunakan untuk mengukur job demands dan job resources juga menunjukkan hasil koefisien validitas diatas 0,3 pada setiap aitemnya. Hal tersebut menunjukkan bahwa aitem-aitem pada skala tersebut valid untuk mengukur konstruk job demands dan job resources. 
Reliabilitas hasil ukur dalam penelitian ini dihitung dengan menggunakan koefisien Alpha Cronbach dimana perhitungannya dilakukan dengan menyajikan satu bentuk skala yang dikenakan hanya sekali saja pada sekelompok responden (single trial-administration). Responden uji coba merupakan bagian dari subjek penelitian (uji coba terpakai). Berdasarkan hasil uji reliabilitas pada kedua skala yang digunakan diperoleh nilai koefisien $\alpha$ sebesar 0,733 untuk skala work engagement, 0,792 untuk job demands, dan 0,920 untuk job resources. Reliabilitas dinyatakan dalam koefisien reliabilitas yang angkanya berada dari rentang 0 sampai 1. Semakin tinggi koefisien reliabilitas, atau semakin mendekati angka 1, maka berarti semakin tinggi reliabilitasnya (Azwar, 2008).

\section{Analisis Data}

Teknik analisis data yang digunakan dalam penelitian ini adalah teknik analisis regresi ordinal dengan bantuan program SPSS Statistics Version 22 for Windows. Penggunaan teknik analisis regresi ordinal disesuaikan dengan tujuan dari penelitian ini yang mencoba untuk mengetahui apakah terdapat pengaruh antara job demands dan job resources terhadap work engagement pada guru.

\section{Hasil dan Pembahasan}

Responden pada penelitian ini merupakan guru yang mengajar di sekolah atau madrasah pada jenjang pendidikan SD/sederajat, SMP/sederajat, dan SMA/SMK/sederajat. Jumlah responden dalam penelitian ini adalah 184 orang dengan rincian sebegai berikut:

Tabel 1. Gambaran Responden Berdasarkan Jenis Kelamin

\begin{tabular}{ccc}
\hline Jenis Kelamin & Jumlah & Persentase \\
\hline Laki-laki & 55 & $30 \%$ \\
Perempuan & 129 & $70 \%$ \\
\hline
\end{tabular}

Berdasarkan tabel 1 di atas menunjukkan bahwa mayoritas responden berjenis kelamin perempuan dengan persentasi sebesar $70 \%$ dan sebanyak $30 \%$ sisanya adalah laki-laki. Selanjutnya gambaran responden berdasarkan jenjang pendidikan siswa yang diajar: 
Tabel 2. Gambaran Responden Berdasarkan Jenjang Pendidikan Siswa

\begin{tabular}{ccc}
\hline Jenjang Pendidikan Siswa & Jumlah & Persentase \\
SD & 57 & $31 \%$ \\
SMP & 67 & $36 \%$ \\
SMA & 44 & $24 \%$ \\
SMK & 16 & $9 \%$ \\
\hline
\end{tabular}

Berdasarkan tabel 2 dapat dilihat bahwa persentase responden terbesar adalah guru yang mengajar siswa pada jenjang pendidikan SMP/sederajat sebanyak $36 \%$. Kemudian guru yang mengajar siswa pada jenjang pendidikan SD/sederajat sebanyak $31 \%$, pada jenjang SMA/sederajat sebanyak 24\%, dan pada jenjang SMK sebanyak 9\%. Berdasarkan data tersebut, maka karakteristik populasi yang diinginkan penulis yaitu guru yang mengajar di sekolah atau madrasah dengan jenjang pendidikan siswa yang diajar adalah SD, SMP, SMA, dan SMK, telah terpenuhi. Berdasarkna hasil analisis yang dilakukan, diperoleh hasil bahwa tidak terdapat pengaruh antara job demands dan job resources terhadap work engagement. Hal tersebut dapat dilihat pada nilai signifikansi job demands yang tidak signifikan karena nilai signifikansinya sebesar 0,055 $(>0,05)$.

Tabel 3. Uji Pengaruh Job Demands dan Job Resources terhadap Work Engagement pada

\begin{tabular}{cc}
\multicolumn{2}{c}{ Guru } \\
\hline Cox and Snell & .149 \\
Nagelkerke & .174 \\
McFadden & .084 \\
\hline
\end{tabular}

\begin{tabular}{ccccc} 
& & Estimate & Std. Error & Sig. \\
\hline \multirow{2}{*}{ Threshold } & [work engagemnt_1] & 4.187 & 1.296 & .001 \\
& [work engagement_2] & 7.010 & 1.372 & .000 \\
Location & Job Demands & -.077 & .040 & .055 \\
& Job Resources & .061 & .012 & .000 \\
\hline
\end{tabular}

Berdasarkan hasil uji hipotesis yang telah dilakukan, dapat dilihat bahwa tidak ada pengaruh dari job demands dan job resources terhadap work engagement pada guru. Hasil ini sejalan dengan hasil penelitian dari Simbula, dkk. (2012) pada guru. Pada penelitiannya Simbula, dkk. (2012) mengatakan bahwa tidak ada perbedaan yang signifikan pada work engagement guru yang mengalami job demands rendah maupun tinggi. Menurut Simbula, dkk. (2012), tidak adanya perbedaan yang signifikan dikarenakan job demands tidak dikategorikan secara spesifik. Ketika job demands dikategorikan secara spesifik 
menjadi hindrance demands dan challenge demands, maka terlihat perbedaan pengaruhnya pada work engagement.

Apabila mengacu pada kategorisasi yang dilakukan oleh Simbula, dkk. (2012), maka overload masuk pada kategori challenge demands. Pertimbangan alasan overload sebagai job demands tidak memberikan pengaruh pada work engagement adalah kemungkinan overload tidak dianggap sebagai tantangan oleh guru yang menjadi subyek penelitian ini. Dengan kata lain, walaupun overload merupakan salah satu bentuk dari beban kerja, tetapi tidak dianggap sebagai beban kerja melainkan dianggap sebagai tantangan yang membuat guru merasa tetap engaged pada pekerjaannya.

Pendapat ini sejalan dengan teori eustress yang dikemukakan Selye (1983) yang menyebutkan bahwa walaupun pekerjaan memberikan beban atau tekanan pada karyawan, tetapi mereka juga merasa memiliki tujuan, makna, ketenangan psikologis, dan semangat untuk menghadapi kesulitan. Hargrove, dkk. (2015) juga menyebutkan bahwa eustress memberikan pengaruh positif pada harapan, dan vigor. Berdasarkan penjelasan menggunakan teori eustress dapat disimpulkan bahwa pada saat guru mendapatkan beban kerja kemudian guru tersebut memunculkan respon positif berupa esutress, maka hal tersebut justru akan menguatkan harapan dan vigor.

Pendapat lain dikemukakan oleh Li, dkk. (2015) yang menyebutkan bahwa guru yang memiliki nilai-nilai yang sama dengan sekolah tempatnya bekerja akan meningkatkan work engagement guru tersebut. Kesamaan nilai-nilai yang dianut membuat guru merasa bangga dengan perannya dan lebih engaged terhadap pekerjaannya. Guru yang memiliki kesaman nilai-nilai dengan sekolah tempatnya bekerja akan menunjukkan motivasi yang tinggi dalam bekerja.

\section{Kesimpulan dan Saran}

\section{Kesimpulan}

Berdasarkan penelitian yang telah dilakukan, dapat ditarik kesimpulan bahwa job demands dan job resources tidak memiliki pengaruh terhadap work engagement guru. Hal ini dapat dilihat dari hasil uji regresi ordinal yang 
menunjukkan nilai signifikansi job demands lebih besar dari 0,05 yang dianggap tidak signifikan.

\section{Saran}

Pada penelitian ini masih banyak sekali kekurangan, baik secara teori maupun metode yang digunakan. Berdasarkan penelitian ini maka saran yang dapat diberikan adalah agar peneliti selanjutnya dapat memperluas dan mengelaborasi variabel lain yang mungkin berpengaruh pada work engagement pada guru. Seperti yang dilakukan Xanthapoulou, dkk. (2009) dengan meneliti pengaruh personality terhadap work engagement dan Jawahar dan Liu (2017) yang meneliti pengaruh proactive personality secara lebih spesifik.

\section{DAFTAR PUSTAKA}

Azwar, S. (2008). Penyusunan Skala Psikologi, Edisi I. Yogyakarta: Pustaka Pelajar.

Bakker, A. B., (2017). Strategic and Proactive Approacher to Work Engagement. Organizational Dynamics, 46, 67-75

Bakker, A. B., \& Bal, P. M.. (2010). Weekly Work Engagement and Performance: A Study among Starting Teachers. Journal of Occupational and Organisational Psychology. 83. 189-206

Bakker, A. B., Demerouti, E., \& Verbeke, W. (2004). Using the job demandsresources model to predict burnout and performance. Human Resource Management, 43, 83-104.

Bakker, A. B., \& Demerouti, E. (2007). The job demands-resources model: state of the art. Journal of Managerial Psychology, 22, 309-328.

Barnes, D. C., \& Collier, J. E. (2013). Investigating work engagement in the service environment. Journal of Services Marketing, 27, 485-499. doi:10.1108/jsm-01-2012-0021

Basikin. (2007). Vigor, Dedication, and Absorption: work engagement Among Secondary School English Teacher in Indonesia. (Cnoference Paper: AARE 2007 - BAS 07349)

Burke, R. J. \& El-Kot, G. (2010). Work Engagement Among Managers and Profesionals in Egypt. African Journal Economic and Management Studies, $1(1), 42-60$. 
Bhuvanaiah, T. (2016). Predicting Employee Work Engagement Levels, Determinants and Performance Outcome: Empirical Validation in The Context of an Information Technology Organization. Global Business Review. 17(4), 934-951.

Chen, S. I.. (2017). Work Engagement and ItsAntecedents and Consequences: A case of Lecturers Teaching Synchronous Distance Education Courses. Computers in Human Behavior. 72, 655-663.

Christian, M. S., Garza, A. S., \& Slaughter, J. E. (2011). Work engagement: A quantitative review and test of its relations with task and contextual performance. Personality Psychology, 64(1), 89-136.

Eldor, L., Harpaz, I., Westman, M.. (2016). The Work/Nonwork Spillover: The Enrichment Role of Work Engagement. Journal of Leadership \& Organizational Studies. 1-14

Halbesleben, J.R.B., 2010. A meta-analysis of work engagement: Relationships with burnout, demands, resources, and consequences. In: Bakker, A.B. and Leiter, M.P. (Eds.), Work engagement: A handbook of essential theory and research. Psychology Press, New York, NY, pp. 102-117.

Hakanen, J. J., Bakker, A. B., \& Schaufeli, W. B. (2006). Burnout and work engagement among teachers. Journal of School Psychology, 43, 495-513.

Hakanen, J., Schaufeli, W.B., \& Ahola, K. (2008). The Job Demands-Resources model: A three-year cross-lagged study of burnout, depression, commitment, and work engagement. Work \& Stress, 22, 224-241.

Hargrove, M. B., Becker, W. S., \& Hargrove, D. F. (2015). The HRD eustress model: Generating positive stress with challenging work. Human Resource Development Review, 14(3), 279-298.

Jackson, L. \& Rothmann, S.. (2005). Work-related Well-Being of Educators in District of The North-West Province. Prespective in Education. 23(3), 107122.

Jawahar, I. M. \& Liu, Y. (2017). Why are Proactive People More Satisfied with Their Job, Career, and Life? An Examination of The Role Of Work Engagement. Journal Career Development. 44(4), 344-358.

Karatepe, O. M. (2012). Job resources, work engagement, and hotel employee outcomes: A time-lagged analysis. Economic Research, 25, 644-665. 
Laschinger, H. K. S. (2012). Job and career satisfaction and turnover intentions of newly graduated nurses. Journal of Nursing Management, 20, 472-484. doi:10.1111/j.1365-2834.2011.01293.x

Matthysen, M. \& Chantel, H.. (2018). The Relationship between Readiness to Change and Work Engagement: A Case Study in An Accounting Firm Undergoing Change. SA Journal of Human Resources Management. 16(0), a855

Moreire-Fontan, E., Gracia-Senoran, M., Conde-Rodriguez, A. (2019). Teachers' ICT-related self-efficacy, job resources, and positive emotions: Their structural relations with autonomous motivation and work engagement. Computer \& Education. 134, 63-77.

Neuman, W. L. (2014). Social Research Methods: Qualitative and Quantitative Approach (4thed). New York: Allyn \& Bacon.

Rich, B. L., Lepine, J. A., \& Crawford, E. R. (2010). Job engagement: Antecedents and effects on job performance. Academy of Management Journal, 53, 617-635.

Rothmann, S. \& Jordaan, G. M. E., (2006). Job Demands, Job Resources and Work Engagement of Academic Staff in South African Higher Education Institiutions. SA Journal of Industrial Psychology, 32 (4), 87-96.

Sadeghl, S. \& Sattari, S. (2018). A Comparative Study of Job Motivation and Work Engagement among Teachers Working in Smart and Ordinary Middle and High Schools in Parsabad. Journal of Ecopysiology and Occupational Health. 18(1\&2), 12-17

Salanova, M., Llorens, \& Schaufeli, W.B. (2011). Yes, I can, I feel good and just do it: On gain spirals of efficacy beliefs, affect and engagement. Applied Psychology: An International Review, 60, 255-285.

Salanova, M., Schaufeli, W.B., Xanthopoulou, D. \& Bakker, A.B. (2010). Gain spirals of resources and work engagement. In A.B. Bakker \& M.P. Leiter (Eds.), Work engagement: A handbook of essential theory and research (pp. 118-131). New York: Psychology Press.

Schaufeli, B. W. (2012). Work Engagement. What Do We Know and Where Do We Go?. Romanian Journal of Applied Psychology. 14 (1). 3-10.

Schaufeli, W. B., Bakker, A. B., \& Van Rhenen, W. (2009). How changes in job demands and resources predict burnout, work engagement, and sickness absenteeism. Journal of Organizational Behavior, 30, 893-917. 
Schaufeli, W. B. \& Salanova, M. (2007). Work engagement: An emerging psychological concept and its implications for organizations. In S.W. Gilliland, D.D. Steiner \& D.P. Skarlicki (Eds.), Research in social issues in management: Vol. 5. Managing social and ethical issues in organizations. Greenwich, CT: Information Age Publishers.

Schaufeli, W. B., Salanova, M., Gonzalez-Roma, V. \& Bakker A. B. (2002). The measurement of engagement and burnout and: a confirmative analytical approach. Journal of Happines Studies, 3, 71-92.

Selye, H. (1983). The stress concept: Past, present and future. In C. L. Cooper (Ed.), Stress Research Issues for the Eighties (pp. 1-20). New York, NY: John Wiley \& Sons.

Simbula, S., Chiara, P., Guglielmi, D., \& Fraccaroli, F.. (2012). Teachers' Wellbeing and Effectiveness: The Role of The Interplay between Job Demands and Job Resources. Social and Behavioral Sciences. 69, 729-738.

Soares, M. E., \& Mosquera, P. (2019). Fostering Work Engagement: The Role of The Psychological Contract. Journal of Business Research. 101, 469-476.

Song, J. H., Kim, W., Chai, D. S., \& Bae, S. H.. (2014). The Impact of an Innovative School Climate on Teachers' Knowledge Creation Activities in Korean School: The Mediating Role of Teachers' Knowledge Sharing and Work Engagement. Jurnal of Educational Policy. pp. 179-203

Xanthopoulou, D., Bakker, A. B., Demerouti, E., \& Schaufeli, W. B. (2009). Work engagement and financial returns: A diary study on the role of job and personal resources. Journal of Occupational and Organizational Psychology, 82, 183-200.

Yerleden, S., Durksen, T., \& Klassen, R. M.. (2018). An International Validation of The Engaged Teacher Scale. Teachers and Teaching: Theory and Practice.

Zainuddin, M. (2011). Metodologi Penelitian Kefarmasian Dan Kesehatan. Surabaya: Airlangga University Press 